\title{
Metabolic and blood acid-base responses to prepartum dietary cation-anion difference and calcium content in transition dairy cows
}

\author{
X. Zhang, ${ }^{1,2 *} \odot$ K. M. Glosson, ${ }^{3 *} \odot$ S. S. Bascom, ${ }^{4} \odot$ A. D. Rowson, ${ }^{4} \odot$ Z. Wang, ${ }^{2}$ and J. K. Drackley ${ }^{3} \dagger \odot($ \\ ${ }^{1}$ Institute of Plateau Animals, Sichuan Academy of Grassland Sciences, Chengdu, P. R. China 611731 \\ ${ }^{2}$ Low Carbon Breeding Cattle and Safety Production-University Key Laboratory of Sichuan Province, Animal Nutrition Institute, \\ Sichuan Agricultural University, Chengdu, P. R. China 611130 \\ ${ }^{3}$ Department of Animal Sciences, University of Illinois, Urbana 61801 \\ ${ }^{4}$ Phibro Animal Health Corporation, Teaneck, NJ 07666-6712
}

\begin{abstract}
Dairy cows commonly undergo negative Ca balance accompanied by hypocalcemia after parturition. A negative dietary cation-anion difference (DCAD) strategy has been used prepartum to improve periparturient $\mathrm{Ca}$ homeostasis. Our objective was to determine the influence of a negative DCAD diet with different amounts of dietary $\mathrm{Ca}$ on the blood acid-base balance, blood gases, and metabolic adaptation to lactation. Multiparous Holstein cows $(\mathrm{n}=81)$ were blocked into 1 of 3 dietary treatments from $252 \mathrm{~d}$ of gestation until parturition: (1) positive DCAD diet and low $\mathrm{Ca}(\mathrm{CON}$; containing $+6.0 \mathrm{mEq} / 100 \mathrm{~g} \mathrm{DM}, 0.4 \% \mathrm{DM} \mathrm{Ca}) ;(2)$ negative DCAD diet and low $\mathrm{Ca}(\mathrm{ND} ;-24.0 \mathrm{mEq} / 100$ g DM, $0.4 \%$ DM Ca); or (3) negative DCAD diet plus high $\mathrm{Ca}$ supplementation (NDCA; $-24.1 \mathrm{mEq} / 100 \mathrm{~g}$ DM, $2.0 \%$ DM Ca). There were 28, 27, and 26 cows for $\mathrm{CON}, \mathrm{ND}$, and NDCA, respectively. Whole blood was sampled at $0,24,48$, and $96 \mathrm{~h}$ after calving for immediate determination of blood acid-base status and blood gases. Serum samples collected at $-21,-14,-7$, $-4,-2,-1$, at calving, $1,2,4,7,14,21$, and $28 \mathrm{~d}$ relative to parturition were analyzed for metabolic components. Results indicated that cows fed ND or NDCA had lower blood $\mathrm{pH}$ at calving but greater $\mathrm{pH}$ at $24 \mathrm{~h}$ after calving compared with CON. Blood bicarbonate, base excess, and total $\mathrm{CO}_{2}\left(\mathrm{tCO}_{2}\right)$ concentrations of cows in ND and NDCA groups were less than those of cows in CON at calving but became greater from 24 to $96 \mathrm{~h}$ postpartum. The NDCA cows had lower blood bicarbonate, base excess, and $\mathrm{tCO}_{2}$ at $48 \mathrm{~h}$ and greater partial pressure of oxygen after calving compared with ND. Cows fed ND or NDCA diets had lower serum glucose concentrations than CON cows before
\end{abstract}

Received August 22, 2021.

Accepted October 11, 2021.

*These authors contributed equally to this work.

†Corresponding author: drackley@illinois.edu calving but no differences were observed postpartum. Serum concentrations of total protein and albumin were greater prepartum for cows in ND and NDCA groups than for those in CON. Postpartum serum urea $\mathrm{N}$ and albumin concentrations tended to be higher for ND and NDCA cows. Cows fed ND or NDCA diets had elevated serum total cholesterol concentration prepartum. During the postpartum period, triglycerides and NEFA of cows fed ND or NDCA diets tended to be lower than those of CON. Cows fed the NDCA diet had greater postpartum total cholesterol in serum and lower NEFA concentration at calving than ND. In conclusion, feeding a prepartum negative DCAD diet altered blood acid-base balance and induced metabolic acidosis at calving, and improved protein and lipid metabolism. Supplementation of high Ca in the negative DCAD diet prepartum was more favorable to metabolic adaptation to lactation in dairy cows than the negative DCAD diet with low Ca.

Key words: transition cow, dietary cation-anion difference, calcium, acid-base balance

\section{INTRODUCTION}

The transition period, a critical physiological stage for dairy cows, not only invokes acute alterations of energy and protein metabolism but also mineral metabolism, being linked closely with health, immune status, and productive performance after parturition (Drackley et al., 2005). Owing to dramatically increased demand of Ca for initiation of lactation, postcalving dairy cows often have hypocalcemia. The failure of adaptation to the substantial Ca drop may lead to milk fever, which has severe clinical symptoms and is life threatening (Horst et al., 1997). More common is subclinical hypocalcemia (SCH, total Ca $\leq 2.125 \mathrm{mmol} / \mathrm{L}$; Leno et al., 2017), which still affects around $50 \%$ of cows in second lactation or greater (Goff, 2014). Research has demonstrated that cows with SCH have decreased feed intake, leading to worsening of negative energy balance (NEB) and 
an increased occurrence of metabolic disorders (Chamberlin et al., 2013; Martinez et al., 2018; Trevisi and Minuti, 2018). Hence, maintenance of Ca homeostasis around parturition has attracted widespread interest in the dairy industry due to its considerable negative effect on transition cows.

High Ca ingestion prepartum was assumed to be a potential predisposing factor for hypocalcemia (Goings et al., 1974). A low dietary Ca strategy to prevent hypocalcemia has been used but is problematic to apply because of the difficulty in restricting absorbable $\mathrm{Ca}$ to $<20 \mathrm{~g} / \mathrm{d}$. Researchers later proved that metabolic alkalosis is the primary cause of inhibition of parathyroid hormone (PTH) action in restoring Ca homeostasis (Constable et al., 1997; Goff, 2008). Feeding an acidogenic diet before calving can prevent hypocalcemia through enhancement of postpartum blood Ca (Sakha et al., 2014). Reducing dietary DCAD was applied to induce a compensated metabolic acidosis before calving, which increases Ca flux by stimulating Ca resorption from bone and $\mathrm{Ca}$ excretion by the kidney, thereby enhancing PTH function on intestinal Ca absorption and bone resorption after calving (Goff, 2008).

Because of the greater bone Ca mobilization and urinary Ca excretion induced by feeding a negative DCAD diet (Vagnoni and Oetzel, 1998), our hypothesis was that feeding high dietary $\mathrm{Ca}$ in conjunction with an acidogenic diet might replenish the mobilized and excreted Ca faster, resulting in a lower occurrence rate of $\mathrm{SCH}$ following calving. Although an acidogenic dietary strategy is applied, a sufficient Ca flux in the digestive tract can be available for absorption under regulation of stimulated PTH function. The model created by Lean et al. (2006) via meta-analysis recommended that prepartum dietary Ca be above $2.0 \% \mathrm{DM}$ to reduce risk of milk fever. Studies conducted to investigate the interaction of prepartum dietary $\mathrm{Ca}$ along with an acidogenic diet on $\mathrm{Ca}$ homeostasis remain scarce. Results of Oba et al. (2011) indicated that high $\mathrm{Ca}$ in a low DCAD diet could shorten recovery time from loss of blood Ca induced by EDTA challenge. Additionally, Amundson et al. (2018) demonstrated that feeding a low DCAD diet with high dietary $\mathrm{Ca}$ increased the amount of EGTA required to place cows in a state of $\mathrm{SCH}$, suggesting an increased amount of rapidly available $\mathrm{Ca}$ in cows fed a low DCAD, high Ca diet. Recently, we (Glosson et al., 2020) reported little effect of high Ca supplementation in a negative DCAD diet on blood Ca concentration or production of Holstein cows, but their reproductive performance including uterine health and fertility was improved by the higher dietary Ca (Ryan et al., 2020). How the blood acid-base balance system and metabolism around parturition respond to a negative DCAD diet with or without supplemental dietary
$\mathrm{Ca}$ is still unclear. To achieve better understanding of the metabolic response of transition cows to prepartum acidogenic diets accompanied by different $\mathrm{Ca}$ additions, the objectives of our study were to determine the influences of prepartum dietary negative DCAD and Ca concentration on blood acid-base status and metabolic indicators in blood of transition cows.

\section{MATERIALS AND METHODS}

\section{Experimental Design, Cows, and Diets}

Part of the research design and methods, as well as production and reproduction responses have been reported by Glosson et al. (2020) and Ryan et al. (2020). The Institutional Animal Care and Use Committee of the University of Illinois approved all procedures (protocol 16115). Multiparous Holstein cows (second or third gestation, $\mathrm{n}=81$ ) diagnosed with a single calf were the experimental unit. Cows were enrolled at $-50 \mathrm{~d}$ before expected parturition and moved into sand-bedded freestalls in pens with an electronic gate individual feeder system (American Calan). Parturient cows were moved into a box stall bedded with wheat straw within the same barn. Calves were removed from cows immediately after birth and fed colostrum following standard protocols. After parturition, fresh cows were housed in individual tie stalls bedded with sand over rubber mattresses. Cows were milked 3 times daily.

The experiment was conducted as a randomized complete block design. Enrolled cows were blocked and balanced according to parity, milk yield of previous lactation, initial BCS at dry off, and days to expected calving. Within each block, cows were assigned randomly to 1 of 3 treatments from $-28 \mathrm{~d}$ before expected calving to parturition. Treatments were (1) control diet of positive DCAD and low dietary $\mathrm{Ca}(\mathbf{C O N} ;+6$ $\mathrm{mEq} / 100$ g DM DCAD, 0.4\% DM Ca); (2) negative DCAD diet and low $\mathrm{Ca}$ (ND; $-24 \mathrm{mEq} / 100 \mathrm{~g}$ DM DCAD, $0.4 \%$ DM Ca); and (3) negative DCAD and high $\mathrm{Ca}$ diet (NDCA; $-24 \mathrm{mEq} / 100 \mathrm{~g}$ DM DCAD, $2.0 \% \mathrm{DM}$ Ca). There were 28,27 , and 26 cows for CON, ND, and NDCA, respectively. The number of cows per treatment was based on power analysis for DMI and milk yield (Glosson et al., 2020). The amount of anionic salt (Animate, Phibro Animal Health Corporation) fed was adjusted via determination of urine $\mathrm{pH}$ by portable $\mathrm{pH}$ meter to remain in the range of 5.5 to 6.0. After calving, cows from all treatments received the same lactation diet through 30 DIM. Diets prepartum and postpartum (Table 1) fed as TMR were formulated using a software program (AMTS.Cattle.Pro version 4.16.3.2; AMTS LLC). The main ingredients and water to maintain the final DM content of TMR at about 
$45 \%$ were mixed daily as a basal diet using a TMR mixer (Keenan Systems). Different treatment premixes were added into the basal diet and mixed separately (Data Ranger, American Calan). The diets were prepared and offered to cows at $0600 \mathrm{~h}$ once daily and were pushed up frequently to achieve ad libitum intake. The daily feed amount offered to each cow was determined by feed refusal of previous day to target $<10 \%$ refusal. The DM content of feed ingredients was measured once weekly and adjusted accordingly to maintain the DM ratio of ingredients in the TMR. Diet ingredients and TMR were sampled weekly, stored at $-20^{\circ} \mathrm{C}$, and composited monthly to analyze nutrients at a commercial laboratory (Dairy One, Ithaca, NY).

\section{Sampling and Analyses}

Blood samples $(10 \mathrm{~mL})$ were collected from the coccygeal vein or artery into heparinized vacuum tubes (BD Vacutainer Systems) at calving, 24, 48, and $96 \mathrm{~h}$ $( \pm 1 \mathrm{~h})$ postpartum. After sampling, blood $\mathrm{pH}$, partial pressure of $\mathrm{CO}_{2}\left(\mathrm{pCO}_{2}\right)$, partial pressure of $\mathrm{O}_{2}\left(\mathrm{pO}_{2}\right)$, base excess, bicarbonate $\left(\mathrm{HCO}_{3}^{-}\right)$, total $\mathrm{CO}_{2}\left(\mathrm{tCO}_{2}\right)$, $\mathrm{Na}, \mathrm{K}$, hematocrit and hemoglobin concentrations were determined within 10 min using a test cartridge (CG8+, Abbott Point of Care Inc.) in a handheld analyzer (VetScan iSTAT, Abaxis). A minimal chance for aerobic contamination was present when transferring the sample to the test cartridge, but all samples were handled the same. Therefore, the discussion of results will focus on the differences between treatments and not the absolute value of the blood gas measurements.

Another series of blood samples was taken from the coccygeal vein before the morning feeding every Monday, Wednesday, and Friday and daily from $-7 \mathrm{~d}$ until calving day to ensure samples were available from the actual $-30,-21,-14,-7,-4,-2$, and $-1 \mathrm{~d}$ relative to calving. Postpartum samples were collected at $0,1,2,4,7,14,21$, and $28 \mathrm{~d}$ after parturition. Blood was sampled into vacuum serum separator tubes (BD Vacutainer Systems) and centrifuged at $1,900 \times g$ for 15 min at $4^{\circ} \mathrm{C}$ to obtain serum. Aliquots of serum were stored at $-20^{\circ} \mathrm{C}$ until analysis. Commercial reagents (system quantitative determination reagents, Beckman Coulter, Inc.) were used in an auto-analyzer (Beckman Coulter AU680 Analyzer, Beckman Coulter, Inc.) at the Clinical Pathology Laboratory in the University of Illinois College of Veterinary Medicine to measure serum concentrations of total protein, urea N, albumin, glucose, total cholesterol, triglyceride, $\mathrm{Na}, \mathrm{K}, \mathrm{Cl}$ and $\mathrm{HCO}_{3}{ }^{-}$. Globulin content in serum was calculated as total protein minus albumin. The $\mathrm{Na}, \mathrm{K}$, and $\mathrm{Cl}$ were used to calculate anion gap according to the following
Table 1. Ingredients composition (\% of DM) of the close-up and lactation (LACT) diets fed as TMR

\begin{tabular}{|c|c|c|c|c|}
\hline \multirow[b]{2}{*}{ Ingredient } & \multicolumn{3}{|c|}{ Treatment $^{1}$} & \multirow[b]{2}{*}{ LACT } \\
\hline & $\mathrm{CON}$ & ND & NDCA & \\
\hline Corn silage & 32.10 & 32.10 & 32.10 & 36.61 \\
\hline Wheat straw & 36.31 & 36.31 & 36.31 & 2.34 \\
\hline Alfalfa hay & - & - & - & 11.26 \\
\hline Corn gluten feed & 8.25 & 8.25 & 8.25 & 8.34 \\
\hline Corn grain & - & - & - & 18.81 \\
\hline Soybean hulls & 6.60 & 6.60 & 6.60 & 4.32 \\
\hline Soybean meal & 5.78 & 5.78 & 5.78 & - \\
\hline ProVAAl AAdvantage ${ }^{2}$ & 2.48 & 2.48 & 2.48 & 1.87 \\
\hline Canola meal & - & - & - & 11.79 \\
\hline Rumen-protected lysine & - & - & - & 0.63 \\
\hline Rumen-protected methionine & - & - & - & 0.15 \\
\hline Animate $^{3}$ & - & 4.13 & 4.13 & - \\
\hline Calcium carbonate & - & - & 2.87 & - \\
\hline Wheat middlings & 6.20 & 3.38 & 0.83 & - \\
\hline Clay & 1.24 & 0.41 & - & - \\
\hline Sodium chloride & 0.08 & - & - & - \\
\hline Sodium monophosphate & - & 0.08 & 0.16 & - \\
\hline Magnesium sulfate $7 \mathrm{H}_{2} \mathrm{O}$ & 0.58 & - & - & - \\
\hline Magnesium oxide & 0.33 & - & - & - \\
\hline UI prepartum mineral premix ${ }^{4}$ & 0.17 & 0.02 & 0.02 & - \\
\hline UI lactation mineral mix ${ }^{5}$ & - & - & - & 3.70 \\
\hline Potassium carbonate & - & - & - & 0.13 \\
\hline Monensin & 0.02 & 0.02 & 0.02 & 0.01 \\
\hline Vitamin $\mathrm{A}^{6}$ & 0.01 & 0.01 & 0.01 & 0.03 \\
\hline Vitamin $D^{6}$ & 0.01 & 0.01 & 0.01 & 0.01 \\
\hline Vitamin $E^{6}$ & 0.29 & 0.29 & 0.29 & 0.05 \\
\hline
\end{tabular}

${ }^{1}$ The control diet (CON) was formulated to offer a positive DCAD that averaged $+6 \mathrm{mEq} / 100 \mathrm{~g}$ and dietary $\mathrm{Ca}$ at $0.40 \% \mathrm{DM}$. The negative DCAD (ND) and negative DCAD plus Ca supplementation (NDCA) diets were formulated to offer a negative DCAD that averaged -24 $\mathrm{mEq} / 100 \mathrm{~g}$ with dietary Ca at either $0.40 \% \mathrm{DM}$ or $2.0 \% \mathrm{DM}$.

${ }^{2}$ Perdue Agribusiness Animal Nutrition.

${ }^{3}$ Composed of $38.0 \%$ CP, $3.2 \%$ ether extract, $3.1 \%$ sugar, $5.8 \%$ starch, $15.9 \% \mathrm{NDF}, 1.4 \% \mathrm{Ca}, 0.4 \% \mathrm{P}, 4.8 \% \mathrm{Mg}, 5.4 \% \mathrm{~S}$, and $13.9 \% \mathrm{Cl}$ (Phibro Animal Health Corp.).

${ }^{4}$ The University of Illinois mineral and vitamin mix provided $5 \% \mathrm{Mg}$, $10 \% \mathrm{~S}, 7.5 \% \mathrm{~K}, 2.0 \% \mathrm{Fe}, 3.0 \% \mathrm{Zn}, 3.0 \% \mathrm{Mn}, 5,000 \mathrm{mg} / \mathrm{kg} \mathrm{Cu}, 250 \mathrm{mg} /$ $\mathrm{kg} \mathrm{I}, 40 \mathrm{mg} / \mathrm{kg} \mathrm{Co}, 150 \mathrm{mg} / \mathrm{kg}$ Se, 2,200 kIU/kg vitamin A, $660 \mathrm{kIU} /$ $\mathrm{kg}$ vitamin $\mathrm{D}_{3}$, and $7,700 \mathrm{IU} / \mathrm{kg}$ vitamin $\mathrm{E}$.

${ }^{5}$ The University of Illinois mineral and vitamin mix provided $12.5 \%$ $\mathrm{Ca}, 14.1 \% \mathrm{Na}, 9.6 \% \mathrm{Cl}, 3.2 \% \mathrm{Mg}, 6.5 \% \mathrm{~K}, 0.19 \% \mathrm{~S}, 26.9 \mathrm{mg} / \mathrm{kg} \mathrm{Co}$, $301 \mathrm{mg} / \mathrm{kg} \mathrm{Cu}, 40.2 \mathrm{mg} / \mathrm{kg} \mathrm{I}, 678 \mathrm{mg} / \mathrm{kg} \mathrm{Fe}, 1,519 \mathrm{mg} / \mathrm{kg} \mathrm{Mn}, 8.62$ $\mathrm{mg} / \mathrm{kg} \mathrm{Se}, 4.47 \mathrm{mg} / \mathrm{kg}$ organic Se, $1,621 \mathrm{mg} / \mathrm{kg} \mathrm{Zn}, 43.3 \mathrm{kIU} / \mathrm{kg}$ vitamin A, $10.9 \mathrm{kIU} / \mathrm{kg}$ vitamin $\mathrm{D}_{3}, 466.4 \mathrm{IU} / \mathrm{kg}$ vitamin $\mathrm{E}, 4.23 \mathrm{mg} / \mathrm{kg}$ biotin, $46.6 \mathrm{mg} / \mathrm{kg}$ thiamine, and $0.35 \mathrm{~g} / \mathrm{kg}$ monensin.

${ }^{6}$ Vitamins A, D, and E contained 30,000 kIU/kg, 5,009 kIU/kg, and $44,000 \mathrm{IU} / \mathrm{kg}$, respectively.

formula (Pardon et al., 2018): Anion gap $=\left(\mathrm{Na}^{+}+\mathrm{K}^{+}\right)$ $-\left(\mathrm{Cl}^{-}+\mathrm{HCO}_{3}^{-}\right)$. A commercial kit (Wako Chemicals USA Inc.) was used to determine nonesterified fatty acids (NEFA) following the manufacturer's instructions via 96-well plate and microplate spectrophotometer (BioTek Instruments, Inc.). Serum samples from d 0 to 28 DIM were measured for BHB concentration (Cat \# RB 1007, Randox Laboratories Ltd.) with the same instrument. 


\section{Statistical Analysis}

The postpartum period was divided into 3 subperiods: calving, immediate postcalving (defined as 1 , 2 , and $4 \mathrm{~d}$ after calving), and postpartum (defined as 7-28 DIM). Data for different periods were analyzed separately. Statistical analyses were performed using the MIXED procedure of SAS (SAS Institute Inc.). The model included the fixed effects of treatment, time relative to calving as a repeated measurement (with cow as subject), and the interaction of treatment and time, with the random effect of block. Several covariance structures were tested for the repeated measurements, and the one with the lowest Akaike information criterion was selected. Previous milk yield, parity, and initial BCS were used as covariates in the full model but were removed if nonsignificant $(P>0.15)$. For prepartum data, a covariate of pretreatment measurements $(-30$ d) of serum components was tested in the analysis. All data from 5 cows were excluded after treatment with Ca therapy due to clinical milk fever (2 in CON and 3 in ND). A total of 4 cows died or were euthanized for toxic mastitis, acute ketosis, and a broken hip during the fresh period ( 2 in CON and 2 in ND). Data were transformed for statistical analysis as necessary to achieve a normal distribution of residuals. Two preplanned orthogonal contrast statements were evaluated for the following treatment effects: (1) CON versus the average of ND and NDCA for the comparison between positive and negative DCAD diets; and (2) ND versus NDCA for the effect of different amounts of Ca in the negative DCAD diet. Results are presented as least squares means. Statistical significance was declared at $P \leq 0.05$, and tendencies were considered when $0.05<$ $P \leq 0.10$.

\section{RESULTS}

The DMI prepartum, published previously (Glosson et al., 2020), was $12.0,10.0$, and $11.0 \mathrm{~kg} / \mathrm{d}$ for CON, $\mathrm{ND}$, and NDCA, respectively, whereas postpartum DMI was $17.6,18.4$, and $18.8 \mathrm{~kg} / \mathrm{d}$ for the same treatments. Nutrient composition of the diets is shown in Table 2. The $\mathrm{pH}$ of blood in postpartum dairy cows is presented in Table 3 and Figure 1. Blood pH of all treatments was lower at calving, increased after $24 \mathrm{~h}$ postpartum and then reached its peak thereafter. Blood $\mathrm{pH}$ was lower $(P<0.05)$ for cows fed ND or NDCA at calving than those fed CON. We observed an interaction between treatments and DIM $(P<0.01)$, in which blood $\mathrm{pH}$ of cows fed ND or NDCA was higher than CON $(P<$ 0.05 ) at $24 \mathrm{~h}$ postpartum but similar thereafter (Figure 1). The blood $\mathrm{pH}$ of ND and NDCA treatments did not differ $(P>0.10)$. Cows in ND and NDCA groups had lower blood bicarbonate and base excess values at calving than cows fed CON $(P<0.05)$. From 24 to $96 \mathrm{~h}$ after calving, bicarbonate and base excess were significantly greater for ND and NDCA $(P<0.05)$ compared with CON, with a significant difference between ND and NDCA groups at $48 \mathrm{~h}(P<0.05$, Figure 2$)$. For blood gases, $\mathrm{tCO}_{2}$ concentration showed a similar pattern as bicarbonate. Blood $\mathrm{tCO}_{2}$ was significantly lower in cows fed ND or NDCA diet $(P<0.05)$ than CON at calving and the difference reversed at $24 \mathrm{~h}$. The $\mathrm{pCO}_{2}$ at $48 \mathrm{~h}$ after calving differed among treatments $(P<$ $0.05)$ with cows fed $\mathrm{CON}$ showing the lowest $\mathrm{pCO}_{2}$ and cows in ND group were greater than NDCA. Blood $\mathrm{pO}_{2}$ of cows that received the CON diet did not differ from those fed ND or NDCA diets $(P=0.62)$ at $96 \mathrm{~h}$ after calving, and $\mathrm{pO}_{2}$ was greater for cows fed NDCA when compared with ND $(P=0.02)$. There was no significant difference for $\mathrm{Na}$ and $\mathrm{K}$ concentrations among treatments $(P>0.10)$. When all time points were included, we found a significant DIM effect and treatment $\times$ DIM interaction $(P<0.01)$ for hematocrit and hemoglobin concentrations, although no significant difference was observed for the 2 preplanned contrasts over all times.

Serum components for cows fed close-up dietary treatments are shown in Table 4. Serum anion gap throughout the study did not differ among treatments $(P>0.10)$. During the prepartum period, serum bicarbonate concentrations were lower for cows that consumed ND or NDCA $(P<0.01)$ than those fed CON, with a significant difference between ND and NDCA groups $(P<0.01)$. Cows fed ND and NDCA diets had reduced bicarbonate at calving compared with those fed CON $(P<0.01)$. Conversely, in immediate postcalving period (24, 48, and $96 \mathrm{~h}$ postpartum), bicarbonate concentration became significantly higher in ND and NDCA groups $(P<0.01)$.

Prepartum total protein and albumin concentrations of cows fed ND or NDCA diets were significantly greater than those fed CON $(P=0.047$ and $P=0.01)$. Postpartum urea $\mathrm{N}$ concentration tended to be greater with the negative DCAD treatments than CON $(P=$ $0.10)$, with a tendency toward higher albumin in the immediate postcalving period (24-96 h postpartum) period in comparison with CON $(P=0.10)$. For serum glucose, feeding ND or NDCA diets resulted in lower glucose concentration than CON prepartum, although no effect of treatments on glucose was observed at calving and postpartum.

During the prepartum period, cows given ND or NDCA diets had significantly greater total cholesterol concentration than those given CON (Table 5). Immediate postcalving total cholesterol concentrations were greater in NDCA than in ND $(P=0.03)$, and tended to 
Table 2. Nutrient content of the experimental $\operatorname{diets}^{1}( \pm \mathrm{SD} ; \mathrm{DM}$ basis)

\begin{tabular}{lcccc}
\hline & \multicolumn{3}{c}{ Treatment } & \\
\cline { 2 - 4 } Nutrient $^{2}$ & CON & ND & NDCA & LACT \\
\cline { 2 - 4 } DM, \% as fed & $45.9 \pm 2.5$ & $46.8 \pm 2.6$ & $46.3 \pm 2.7$ & $48.3 \pm 1.7$ \\
$\mathrm{CP}, \%$ & $15.1 \pm 1.3$ & $16.6 \pm 1.5$ & $16.4 \pm 1.0$ & $17.8 \pm 0.6$ \\
$\mathrm{ADF}, \%$ & $33.6 \pm 2.2$ & $33.9 \pm 3.6$ & $33.3 \pm 1.9$ & $18.9 \pm 1.9$ \\
aNDFom, \% & $49.3 \pm 2.6$ & $47.7 \pm 4.1$ & $46.9 \pm 4.8$ & $30.4 \pm 1.4$ \\
Starch, \% & $14.1 \pm 2.2$ & $12.7 \pm 2.2$ & $12.8 \pm 1.2$ & $30.8 \pm 1.5$ \\
$\mathrm{Ash}, \%$ & $9.39 \pm 1.0$ & $8.59 \pm 0.3$ & $11.8 \pm 1.6$ & $8.72 \pm 0.8$ \\
$\mathrm{TDN}, \%$ & $60.4 \pm 1.8$ & $61.3 \pm 2.7$ & $59.1 \pm 1.8$ & $68.7 \pm 0.95$ \\
$\mathrm{NE}, \mathrm{Mcal} / \mathrm{kg}$ & $1.36 \pm 0.04$ & $1.41 \pm 0.06$ & $1.36 \pm 0.04$ & $1.58 \pm 0.02$ \\
$\mathrm{Ca}, \%$ & $0.4 \pm 0.06$ & $0.44 \pm 0.05$ & $1.97 \pm 0.6$ & $1.15 \pm 0.32$ \\
$\mathrm{P}, \%$ & $0.42 \pm 0.03$ & $0.43 \pm 0.04$ & $0.44 \pm 0.05$ & $0.49 \pm 0.04$ \\
$\mathrm{Mg}, \%$ & $0.43 \pm 0.08$ & $0.44 \pm 0.03$ & $0.43 \pm 0.05$ & $0.33 \pm 0.02$ \\
$\mathrm{~K}, \%$ & $1.19 \pm 0.06$ & $1.16 \pm 0.07$ & $1.15 \pm 0.05$ & $1.48 \pm 0.08$ \\
$\mathrm{Na}, \%$ & $0.10 \pm 0.03$ & $0.08 \pm 0.02$ & $0.11 \pm 0.03$ & $0.55 \pm 0.03$ \\
$\mathrm{~S}, \%$ & $0.33 \pm 0.15$ & $0.50 \pm 0.06$ & $0.52 \pm 0.04$ & $0.31 \pm 0.02$ \\
$\mathrm{Cl}, \%$ & $0.29 \pm 0.06$ & $0.91 \pm 0.10$ & $0.91 \pm 0.09$ & $0.61 \pm 0.05$ \\
$\mathrm{Fe}, \mathrm{mg} / \mathrm{kg}$ & $119 \pm 38$ & $457 \pm 79$ & $529 \pm 182$ & $370 \pm 62$ \\
$\mathrm{Cu}, \mathrm{mg} / \mathrm{kg}$ & $18.1 \pm 4.5$ & $17.8 \pm 1.1$ & $19.2 \pm 1.7$ & $16.4 \pm 0.8$ \\
$\mathrm{Mn}, \mathrm{mg} / \mathrm{kg}$ & $103 \pm 24$ & $98 \pm 9.7$ & $99 \pm 16$ & $87 \pm 7$ \\
$\mathrm{Zn}, \mathrm{mg} / \mathrm{kg}$ & $94 \pm 17$ & $92 \pm 6.6$ & $96 \pm 12$ & $88 \pm 8$ \\
$\mathrm{DCAD}, \mathrm{mEq} / 100 \mathrm{~g}$ of DM & $6.0 \pm 9.5$ & $-24.0 \pm 6.0$ & $-24.1 \pm 5.3$ & $25.4 \pm 2.3$ \\
\hline
\end{tabular}

${ }^{1}$ The control diet $(\mathrm{CON})$ was formulated to offer a positive DCAD that averaged $+6 \mathrm{mEq} / 100 \mathrm{~g}$ and dietary $\mathrm{Ca}$ at $0.40 \%$ DM. The negative DCAD (ND) and negative DCAD plus Ca supplementation (NDCA) diets were formulated to offer a negative DCAD that averaged $-24 \mathrm{mEq} / 100 \mathrm{~g}$ with dietary Ca at either $0.40 \%$ or $2.0 \%$ DM. LACT = lactation diet.

${ }^{2}$ Experimental diet samples were collected weekly and composited monthly for the nutrient analysis throughout the trial. aNDFom = amylase-treated NDF, OM basis.

be greater in NDCA compared with ND in the postpartum subperiod $(P=0.09)$. A tendency was observed for decreased postpartum serum triglycerides concentration for cows fed ND or NDCA compared with CON for both immediate postcalving and postpartum periods $(P=0.07$ and $P=0.09)$. For the postpartum period, triglycerides of NDCA tended to be greater than that of ND $(P=0.06)$.

We observed a significant increase of NEFA concentrations prepartum for cows fed ND or NDCA diet $(P=0.01)$ compared with CON, whereas NDCA diet resulted in greater prepartum NEFA than ND $(P=$

Table 3. Least squares means for blood acid-base balance and gas indices from 0 to $4 \mathrm{~d}$ after calving for cows fed close-up dietary treatments $\mathrm{CON}, \mathrm{ND}$, or NDCA starting at -28 d relative to expected calving

\begin{tabular}{|c|c|c|c|c|c|c|c|c|}
\hline Variable in blood $^{1}$ & \multicolumn{3}{|c|}{ Treatment $^{2}$} & SEM & DIM & $\operatorname{Trt}^{3} \times$ DIM & \multicolumn{2}{|c|}{ Contrast $^{4}$} \\
\hline $\mathrm{pH}$ & 7.417 & 7.411 & 7.420 & 0.005 & $<0.01$ & $<0.01$ & 0.77 & 0.21 \\
\hline $\mathrm{pO}_{2}, \mathrm{~mm} \mathrm{Hg}$ & 46.6 & 43.1 & 49.2 & 4.6 & 0.27 & 0.17 & 0.62 & 0.02 \\
\hline Base excess, mmol/L & 4.94 & 5.81 & 5.25 & 0.45 & $<0.01$ & $<0.01$ & 0.27 & 0.38 \\
\hline $\mathrm{HCO}_{3}^{-}, \mathrm{mmol} / \mathrm{L}$ & 29.44 & 30.38 & 29.77 & 0.42 & $<0.01$ & $<0.01$ & 0.19 & 0.30 \\
\hline Hematocrit, \% PCV & 27.69 & 27.57 & 27.00 & 0.48 & $<0.01$ & $<0.01$ & 0.45 & 0.36 \\
\hline Hemoglobin, $\mathrm{g} / \mathrm{dL}$ & 9.46 & 9.36 & 9.23 & 0.17 & $<0.01$ & $<0.01$ & 0.39 & 0.55 \\
\hline
\end{tabular}

${ }^{1} \mathrm{pCO}_{2}$ and $\mathrm{pO}_{2}=$ partial pressure of $\mathrm{CO}_{2}$ or $\mathrm{O}_{2} ; \mathrm{tCO}_{2}=$ total $\mathrm{CO}_{2} ; \mathrm{PCV}=$ packed cell volume.

${ }^{2}$ The control diet $(\mathrm{CON})$ was formulated to offer a positive DCAD that averaged $+6 \mathrm{mEq} / 100 \mathrm{~g}$ and dietary Ca at $0.40 \%$ DM. The negative DCAD (ND) and negative DCAD plus Ca supplementation (NDCA) diets were formulated to offer a negative DCAD that averaged -24 $\mathrm{mEq} / 100 \mathrm{~g}$ with dietary Ca at either $0.40 \%$ or $2.0 \% \mathrm{DM}$.

${ }^{3}$ Trt $=$ treatment.

${ }^{4}$ The preplanned contrast statements were (C1) CON versus the average of NDCA and ND and (C2) NDCA versus ND. 
0.03). At calving, the difference reversed, such that cows given NDCA diet had lower NEFA than those fed ND $(P=0.04)$. Postpartum NEFA concentrations tended to be lower for cows fed ND or NDCA treatments compared with those fed CON $(P=0.06)$. Mean serum BHBA concentrations did not differ significantly among treatments.

\section{DISCUSSION}

\section{Blood Acid-Base Balance and Gases}

Blood acid-base balance is of great significance for metabolic activity, providing a stable and appropriate $\mathrm{pH}$ environment for enzymes, membrane permeability, and organ functions. We found that feeding $\mathrm{ND}$ or NDCA diets to dry cows decreased the blood $\mathrm{pH}$ at calving compared with the positive DCAD CON diet, consistent with previous research (Gelfert et al., 2007) and confirming a condition of compensated metabolic acidosis. Urine $\mathrm{pH}$ in this study followed the same pattern (Glosson et al., 2020), in which it was maintained in the range of 5.5 to 6.0 with administration of the negative DCAD diet before calving. In contrast, Seifi et al. (2010) found no change of blood $\mathrm{pH}$ for cows fed a negative DCAD diet. The reason seems to be their much higher DCAD $(-8.2 \mathrm{mEq} / 100 \mathrm{~g})$ compared with the DCAD in our trial $(-24.0 \mathrm{mEq} / 100 \mathrm{~g})$. Likewise, Grünberg et al. (2011) also found no difference in blood $\mathrm{pH}$ but their DCAD was only $-9.0 \mathrm{mEq} / 100 \mathrm{~g}$.

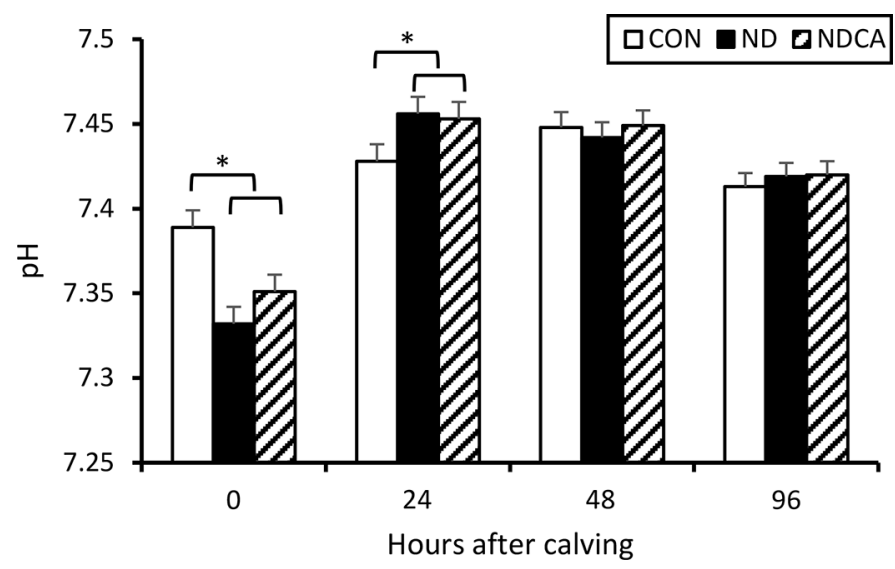

Figure 1. Least squares means for blood $\mathrm{pH}$ from 0 to $4 \mathrm{~d}$ after calving for cows fed different prepartum dietary treatments. The control diet $(\mathrm{CON})$ was formulated to offer a positive DCAD that averaged $+6 \mathrm{mEq} / 100 \mathrm{~g}$ and dietary $\mathrm{Ca}$ at $0.40 \% \mathrm{DM}$. The negative DCAD (ND) and negative DCAD plus Ca supplementation (NDCA) diets were formulated to offer a negative DCAD that averaged -24 $\mathrm{mEq} / 100 \mathrm{~g}$ with dietary $\mathrm{Ca}$ at either $0.40 \%$ or $2.0 \% \mathrm{DM}$. * represents the significant difference $(P<0.05)$ of contrast CON versus (ND and NDCA). Error bars represent SE.
The $\mathrm{HCO}_{3}{ }^{-}$buffer system is significantly correlated with blood $\mathrm{pH}$ and is critical to blood acid-base balance (Yıldızdaş et al., 2004). From the iSTAT and serum biochemical analysis, our preplanned comparisons revealed decreased blood $\mathrm{HCO}_{3}{ }^{-}$prepartum and at calving for cows fed either of the 2 negative DCAD diets. Our results agree with the positive correlation between DCAD and blood $\mathrm{HCO}_{3}{ }^{-}$reported in Charbonneau et al. (2006). Greater blood anions $\left(\mathrm{Cl}^{-}, \mathrm{SO}_{4}{ }^{2-}\right)$ concentration resulting from absorption of anions from the lower DCAD diet have a large influence on humoral acid-base balance. In that case, bicarbonate has to be decreased while $\mathrm{H}^{+}$is increased to maintain blood electric neutrality in the normal range (Stewart, 1983; Gelfert et al., 2010). To stabilize membrane potential of the glomerulus and body fluid electric neutrality, the kidney must excrete excess anions absorbed from the negative DCAD diet (Wu et al., 2008). The significantly lower blood and urine $\mathrm{pH}$ induced by consumption of the negative DCAD diets before calving is similar to previous findings (Liesegang et al., 2007; Martins et al., 2016). Furthermore, in contradiction with an earlier report (Horst et al., 1997), when the NDCA diet was given, the blood $\mathrm{pH}$ did not differ significantly from ND at calving in the present study. Although nonsignificant, the slight difference in blood $\mathrm{pH}$ at calving in cows fed the 2 negative DCAD diets could be attributable to the mild alkalinizing influence of $\mathrm{Ca}^{2+}$ on blood acid-base status, because the majority of supplemental calcium in the NDCA diet originated from calcium carbonate. Feeding either ND or NDCA successfully led to compensated metabolic acidosis. The anion gap was calculated as $\left(\mathrm{Na}^{+}+\mathrm{K}^{+}\right)-\left(\mathrm{Cl}^{-}+\mathrm{HCO}_{3}^{-}\right)$as defined by Pardon et al., (2018), but no significant effect on the prepartum anion gap occurred with the administration of ND and NDCA diets. The reduction of prepartum bicarbonate likely counteracted the inclusion of $\mathrm{Cl}$ from the negative DCAD diets, and the anion $\mathrm{SO}_{4}{ }^{-2}$ was not included in the calculation formula for anion gap.

Regarding the postpartum period, the blood $\mathrm{pH}$, bicarbonate, and base excess of cows fed the 2 negative DCAD diets demonstrated a greater increase and became significantly higher than $\mathrm{CON}$ in immediate postcalving period (24, 48, $96 \mathrm{~h}$ postpartum). At this same time urine $\mathrm{pH}$ was increasing but was still markedly lower than CON in the same cows in the same study (Glosson et al., 2020). Noticeably increased blood pH, bicarbonate, and base excess after calving indicated a quick recovery in acid-base status. We speculate that the rapid increase might be ascribed to the alkalinizing effect of greater blood ionized Ca concentration observed $(0.98,1.11$, and $1.05 \mathrm{~m} M$ at 1 DIM for CON, ND, and NDCA groups, respectively; Glosson et al., 
2020). Another reason for the rapid increase could be the faster recovery of DMI of the positive DCAD lactation diet $(25.4 \mathrm{mEq} / 100 \mathrm{~g} \mathrm{DM})$ after parturition for cows fed the negative DCAD diets prepartum (17.6, 18.4 , and $18.8 \mathrm{~kg} / \mathrm{d}$ for cows fed CON, ND, and NDCA, respectively; Glosson et al., 2020). With the assistance of higher postpartum blood ionized $\mathrm{Ca}$ concentration, chewing, rumination, and smooth muscle contraction of the digestive tract could be more functional and effective (Hansen et al., 2003).

(A)

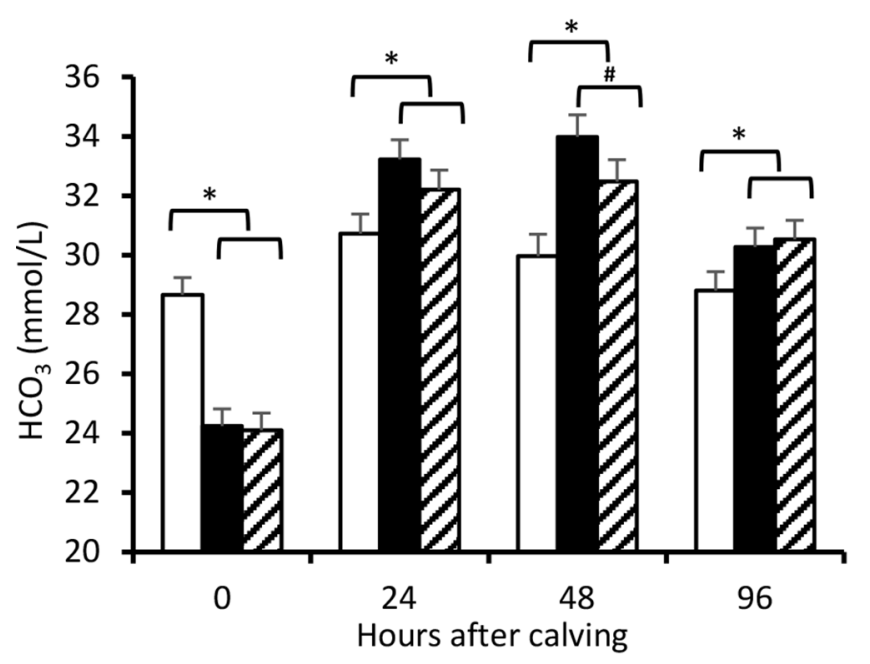

(C)
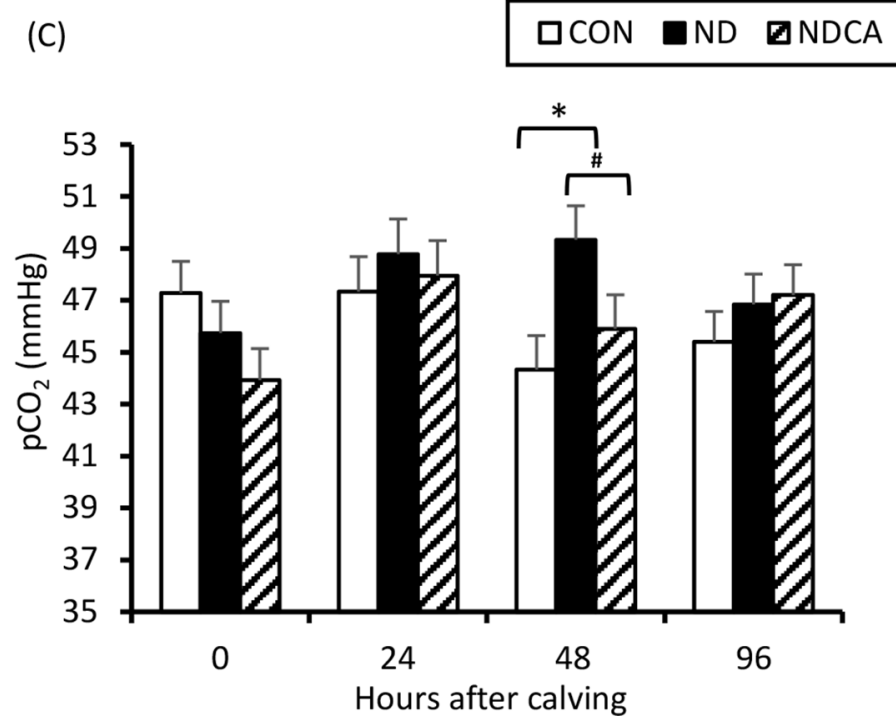

As for blood gases, the measured values using iSTAT analyzer in this study were in good agreement with the venous reference range reported by Higgins (2011) and Lee et al. (2015). Blood $\mathrm{tCO}_{2}$ concentration reflects the sum of $\mathrm{CO}_{2}$, carbonic acid, and bicarbonate in blood circulation but is dominated by the effect of bicarbonate. Although the difference of $\mathrm{pCO}_{2}$ among treatments was not significant at calving, our results showed that $\mathrm{tCO}_{2}$ and $\mathrm{pCO}_{2}$ shared similar fluctuation with bicarbonate levels, in that negative DCAD diets with or without
(B)
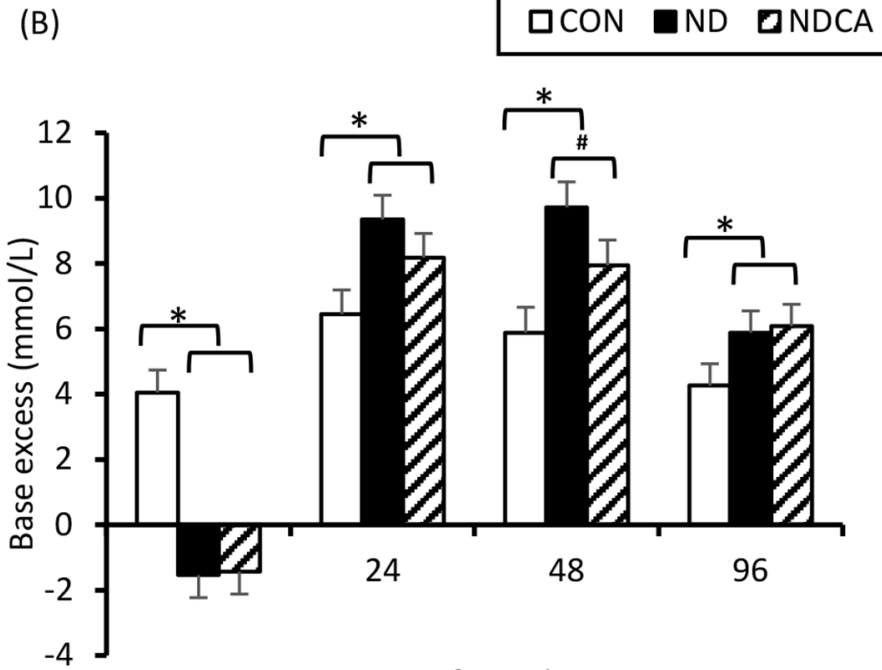

Hours after calving

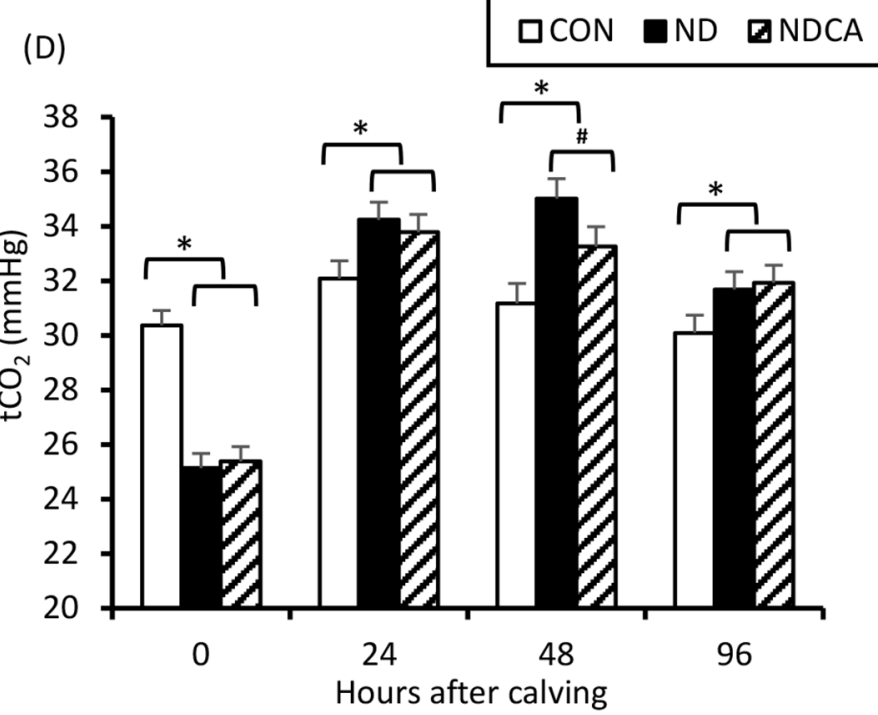

Figure 2. Least squares means for blood acid-base balance and gas indices during 0 to $4 \mathrm{~d}$ after calving for cows fed different prepartum dietary treatments. The control diet $(\mathrm{CON})$ was formulated to offer a positive DCAD that averaged $+6 \mathrm{mEq} / 100 \mathrm{~g}$ and dietary Ca at $0.40 \%$ DM. The negative DCAD (ND) and negative DCAD plus Ca supplementation (NDCA) diets were formulated to offer a negative DCAD that averaged $-24 \mathrm{mEq} / 100 \mathrm{~g}$ with dietary Ca at either $0.40 \%$ or $2.0 \% \mathrm{DM}$. * represents the significant difference $(P<0.05)$ of contrast CON versus $\left(\mathrm{ND}\right.$ and NDCA); \# represents the significant difference $(P<0.05)$ of contrast ND versus $\mathrm{NDCA}$. $\mathrm{pCO}_{2}={\text { partial pressure of } \mathrm{CO}_{2} ; \text { tCO }}_{2}=$ total $\mathrm{CO}_{2}$. Error bars represent SE. 
additional $\mathrm{Ca}$ brought about significant reduction of $\mathrm{tCO}_{2}$. This finding is in line with the investigation of Martins et al. (2016), who reported that blood $\mathrm{tCO}_{2}$ was reduced along with the decrease of dietary DCAD.

Salles et al. (2012) also reported that blood $\mathrm{pCO}_{2}$ was linearly related to dietary DCAD when DCAD was reduced from 40.0 to $-10.0 \mathrm{mEq} / 100 \mathrm{~g}$ DM. Blood $\mathrm{CO}_{2}$ resulting from respiration can dissolve into carbonic acid, and be further transformed to bicarbonate and $\mathrm{H}^{+}$, which acidifies the humoral environment. Hence, under the condition of metabolic acidosis, the $\mathrm{tCO}_{2}$ and $\mathrm{pCO}_{2}$ reduction might represent feedback regulation from low blood $\mathrm{pH}$ and result from increased expiration of $\mathrm{CO}_{2}$ (Block, 1994). Postpartum splanchnic consump- tion of $\mathrm{O}_{2}$, particularly in the liver, could be more than double the average prepartum, with the majority of the increase occurring in the first 11 DIM (Reynolds et al., 2003). This alteration may be ascribed to the nutrient delivery from increased consumption and digestion of greater feed intake, lactation metabolic activity, and hepatic oxidative metabolism of transition dairy cows. In the current study, feeding NDCA brought about greater blood $\mathrm{pO}_{2}$ in the first $4 \mathrm{DIM}$, which might reflect more sufficient $\mathrm{O}_{2}$ supply in circulation for metabolic requirements. Although no effect of treatments was observed on hemoglobin, which binds $\mathrm{O}_{2}$ for blood transport, the increase of $\mathrm{O}_{2}$ concentration provided some evidence that a prepartum acidogenic diet with high $\mathrm{Ca}$ could

Table 4. Least squares means for serum metabolic profile for cows fed close-up dietary treatments CON, ND, or NDCA starting at $-28 \mathrm{~d}$ relative to expected calving

\begin{tabular}{|c|c|c|c|c|c|c|c|c|}
\hline Variable $^{1}$ & \multicolumn{3}{|c|}{ Treatment $^{2}$} & SEM & DIM & $\operatorname{Trt}^{3} \times \mathrm{DIM}$ & \multicolumn{2}{|c|}{ Contrast $^{4}$} \\
\hline \multicolumn{9}{|l|}{ Anion gap, mmol/L } \\
\hline At calving & 19.10 & 19.11 & 18.91 & 0.58 & 0.31 & 0.94 & 0.88 & 0.77 \\
\hline Immediate postcalving & 18.01 & 18.29 & 18.51 & 0.50 & 0.06 & 0.46 & 0.41 & 0.67 \\
\hline Postpartum & 18.06 & 17.70 & 17.93 & 0.43 & $<0.01$ & 0.67 & 0.57 & 0.65 \\
\hline At calving & 24.99 & 21.62 & 22.08 & 0.51 & $<0.01$ & 0.80 & $<0.01$ & 0.50 \\
\hline Immediate postcalving & 26.41 & 28.81 & 28.01 & 0.52 & $<0.01$ & 0.03 & $<0.01$ & 0.18 \\
\hline Postpartum & 25.34 & 25.75 & 25.93 & 0.39 & 0.02 & 0.84 & 0.11 & 0.63 \\
\hline \multicolumn{9}{|l|}{ Urea N, mg/dL } \\
\hline Prepartum & 14.63 & 14.95 & 15.37 & 0.32 & \multirow[t]{2}{*}{$<0.01$} & \multirow[t]{2}{*}{0.88} & 0.14 & 0.29 \\
\hline At calving & 14.34 & 14.29 & 15.52 & 0.60 & & & 0.40 & 0.11 \\
\hline Immediate postcalving & 12.40 & 12.09 & 12.95 & 0.50 & 0.02 & 0.27 & 0.82 & 0.16 \\
\hline Postpartum & 6.76 & 6.66 & 6.71 & 0.11 & $<0.01$ & 0.29 & 0.41 & 0.63 \\
\hline \multicolumn{9}{|l|}{ Albumin, $g / d L$} \\
\hline Prepartum & 3.31 & 3.39 & 3.37 & 0.02 & \multirow[t]{2}{*}{$<0.01$} & \multirow[t]{2}{*}{0.86} & 0.01 & 0.64 \\
\hline At calving & 3.39 & 3.45 & 3.43 & 0.03 & & & 0.14 & 0.70 \\
\hline Immediate postcalving & 3.22 & 3.30 & 3.33 & 0.05 & 0.56 & 0.12 & 0.10 & 0.64 \\
\hline Postpartum & 3.28 & 3.31 & 3.36 & 0.07 & 0.01 & 0.27 & 0.50 & 0.59 \\
\hline \multicolumn{9}{|l|}{ Globulin, $g / d L$} \\
\hline Prepartum & 2.89 & 2.96 & 3.00 & 0.05 & \multirow[t]{2}{*}{$<0.01$} & \multirow[t]{2}{*}{0.99} & 0.19 & 0.62 \\
\hline At calving & 2.54 & 2.58 & 2.65 & 0.06 & & & 0.29 & 0.42 \\
\hline Immediate postcalving & 2.73 & 2.63 & 2.70 & 0.10 & $<0.01$ & 0.06 & 0.59 & 0.63 \\
\hline Postpartum & 3.48 & 3.35 & 3.30 & 0.12 & $<0.01$ & 0.33 & 0.24 & 0.76 \\
\hline \multicolumn{9}{|l|}{ Glucose, $\mathrm{mg} / \mathrm{dL}$} \\
\hline Prepartum & 64.7 & 61.7 & 63.1 & 0.7 & \multirow[t]{2}{*}{$<0.01$} & 0.61 & $<0.01$ & 0.12 \\
\hline At calving & 109.6 & 99.4 & 111.3 & 6.4 & & & 0.54 & 0.15 \\
\hline
\end{tabular}

${ }^{1}$ Blood samples were taken at $\mathrm{d}-30$ (used as a covariate in the model), $-21,-14,-7,-4,-2,-1$, calving, $\mathrm{d}$ 1, 2, 4, 7, 14, 21, and 28 relative to parturition. Samples of d 1,2 and 4 were analyzed separately as immediate postcalving.

${ }^{2}$ The control diet $(\mathrm{CON})$ was formulated to offer a positive DCAD that averaged $+6 \mathrm{mEq} / 100 \mathrm{~g}$ and dietary Ca at $0.40 \%$ DM. The negative DCAD (ND) and negative DCAD plus Ca supplementation (NDCA) diets were formulated to offer a negative DCAD that averaged -24 $\mathrm{mEq} / 100 \mathrm{~g}$ with dietary $\mathrm{Ca}$ at either $0.40 \%$ or $2.0 \% \mathrm{DM}$.

${ }^{3}$ Trt $=$ treatment.

${ }^{4}$ The preplanned contrast statements were $(\mathrm{C} 1)$ CON versus the average of NDCA and ND and (C2) NDCA versus ND. 
contribute to improvement of the metabolic adaptation to parturition in early lactating dairy cows.

\section{Blood Metabolic Profile}

Alterations of total protein, albumin, globulin, and urea $\mathrm{N}$ in transition cows reflect protein availability and $\mathrm{N}$ utilization status. Our study confirmed enhancement of blood total protein and albumin concentrations before calving by feeding negative DCAD diets. A recent trial of Guo et al. (2019) found that serum total protein and albumin concentrations of sows were increased at 1 and 18 DIM by an acidogenic lactation diet. Our findings contradict results reported by Grünberg et al. (2011) who found that feeding a DCAD diet of -9 $\mathrm{mEq} / 100 \mathrm{~g}$ led to a reduction of plasma protein. This might be explained by the differences in DCAD of the diets between the 2 studies. Cows in our study were fed a prepartum diet with a negative DCAD value of -24 $\mathrm{mEq} / 100 \mathrm{~g}$. The changes in albumin and total protein were associated with the higher prepartum blood $\mathrm{Ca}$ concentration that resulted from the acidogenic ration (Glosson et al., 2020). Approximately $40 \%$ of $\mathrm{Ca}$ in circulation is bound with albumin $(80 \%)$ and globulin (20\%; Bazydlo et al., 2014). With respect to postcalving data, cows previously fed negative DCAD diets also had a tendency toward higher serum albumin and urea $\mathrm{N}$ concentrations. A study conducted by Li et al. (2008) revealed that a prepartum diet with low DCAD $(-26.5$ $\mathrm{mEq} / 100 \mathrm{~g}$ ) resulted in a decline of digested $\mathrm{N}$ deposition efficiency compared with a positive DCAD diet, thereby contributing more available $\mathrm{N}$ for milk protein synthesis (Martins et al., 2015). Furthermore, albumin was found to be inversely related to postpartum disease and has been recommended as a disease risk indicator for transition cows by Van Saun (2006). Cows with greater serum albumin concentrations during close-up and fresh periods had lower incidence of diseases. The puerperal response of improved protein metabolism in response to the feeding of a negative DCAD diet could be one of the reasons for the reduction in adverse health score reported in Glosson et al. (2020). Blood albumin was also suggested by Bikle et al. (1986) to be a binding protein for transport of vitamin $\mathrm{D}$, which might benefit bone Ca mobilization and intestinal Ca absorption (Weiss et al., 2015).

Wu et al. (2014) demonstrated a significantly negative effect of a low DCAD diet prepartum on blood glucose with an extended feeding time of more than 3 wk. We also observed that the consumption of negative DCAD diets decreased prepartum blood glucose concentration, perhaps associated with decreased DMI (Yu et al.,

Table 5. Least squares means for serum lipid metabolites for cows fed close-up dietary treatments CON, ND, or NDCA starting at $-28 \mathrm{~d}$ relative to expected calving

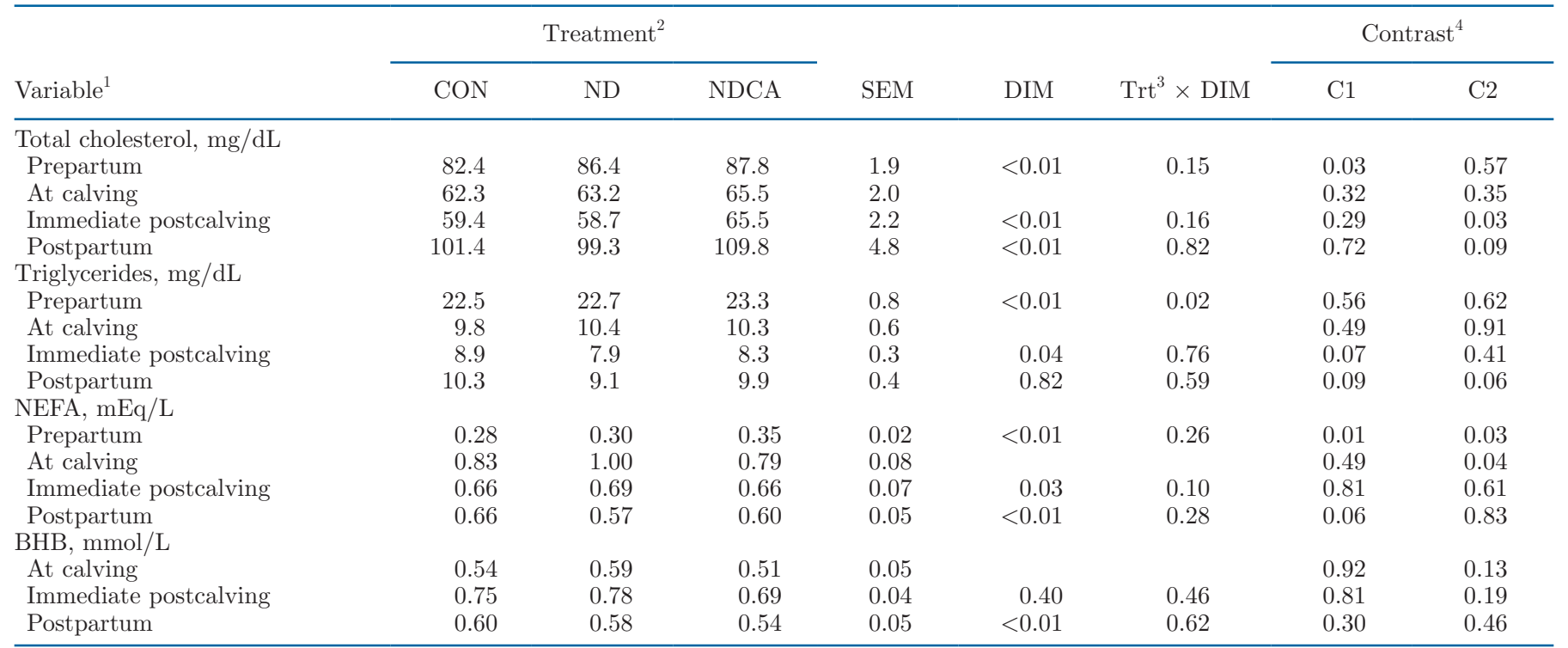

${ }^{1}$ Blood samples were collected at $\mathrm{d}-30$ (used as a covariate in the model), $-21,-14,-7,-4,-2,-1$, calving, $\mathrm{d} 1,2,4,7,14,21$, and 28 relative to parturition. Samples of d 1, 2 and 4 were analyzed separately as immediate postcalving.

${ }^{2}$ The control diet $(\mathrm{CON})$ was formulated to offer a positive DCAD that averaged $+6 \mathrm{mEq} / 100 \mathrm{~g}$ and dietary Ca at $0.40 \% \mathrm{DM}$. The negative DCAD (ND) and negative DCAD plus Ca supplementation (NDCA) diets were formulated to offer a negative DCAD that averaged -24 $\mathrm{mEq} / 100 \mathrm{~g}$ with dietary Ca at either $0.40 \%$ or $2.0 \%$ DM.

${ }^{3}$ Trt $=$ treatment.

${ }^{4}$ The preplanned contrast statements were $(\mathrm{C} 1)$ CON versus the average of NDCA and ND and (C2) NDCA versus ND. 
2016). Meanwhile, negative DCAD plus high Ca had the opposite effect on prepartum glucose although the difference did not reach significance $(P=0.12)$. Diets containing anionic salts are widely believed to decrease feed palatability, according to feeding behavior (Vagnoni and Oetzel, 1998) as well as reduced DMI (Grünberg et al., 2011). As a result of lower feed ingestion, cows given low DCAD diets could have decreased glucose in circulation. On the contrary, in our study cows fed the NDCA diet had elevated close-up DMI compared with ND (10.0 vs. $11.0 \mathrm{~kg} / \mathrm{d}$ DMI for cows fed ND and NDCA diets, respectively; Glosson et al.., 2020), which may be the reason for the numerically higher blood glucose. However, no significant differences occurred for postcalving cows. This finding is supported by the research of Grünberg et al. (2011) who found that feeding a low DCAD diet did not affect insulin response to circulating glucose in parturient dairy cows.

Most cows incur NEB after parturition owing to initiation of lactation and suppression of DMI before and after parturition, which causes an increase in catabolism of body adipose stores (Holcomb et al., 2001, Janovick and Drackley, 2010). Previous anionic diet strategies were applied with the purpose of improving lipid metabolism and reducing metabolic disorders with varying results (Seifi et al., 2010; Weich et al., 2013). Our data demonstrated that cows given negative DCAD diets had higher blood total cholesterol compared with CON before parturition. Furthermore, feeding NDCA resulted in a greater postpartum total cholesterol concentration when compared with ND. This result could indicate a more active lipoprotein synthesis and improvement of nutrient metabolism because cholesterol concentration decreases significantly around parturition (Bionaz et al., 2007). Alternatively, because cholesterol synthesis is active in the intestine to aid dietary lipid absorption, higher serum cholesterol in NDCA postpartum could reflect the greater DMI by those cows. In the current study, postcalving serum triglycerides concentration tended to be lower for cows fed prepartum acidogenic diets. Weich et al. (2013) reported a similar tendency toward reduced triglycerides in response to the feeding of a negative DCAD diet.

The prepartum increase of NEFA for ND and NDCA might be a consequence of suppressed DMI in response to consumption of the acidogenic diet. Following parturition, mobilized NEFA due to NEB contributes to fatty infiltration and accumulation in the liver, leading to accumulation of ketones in circulation (BHB, acetoacetic acid, and acetone), which can cause ketosis (Phillippo et al., 1994). Investigation carried out by Zhang et al. (2020) noted that transition dairy cows with low blood Ca concentration $(<2.0 \mathrm{mmol} / \mathrm{L})$ at $24 \mathrm{~h}$ after calving had higher NEFA and BHB concentrations during the fresh period. In our study, results suggested that NEFA for cows fed negative DCAD diets were lower postpartum in comparison with CON, indicating an improvement of postpartum lipid metabolism. One possible rationalization for this is that higher blood Ca concentrations observed in cows fed a prepartum acidogenic diet might accelerate the recovery of digestive activities (chewing, rumination, and digestive tract peristalsis), which are typically suppressed throughout the immediate periparturient period (Hansen et al., 2003; Weich et al., 2013). Improved activity might subsequently lead to increased DMI and improved energy balance of dairy cows in the fresh period. Our results coincide with those of Apper-Bossard et al. (2006), who observed higher postpartum energy balance in cows that consumed a low DCAD diet. Besides this, NDCA further decreased serum NEFA concentrations although the lower BHB was not significant. Our results demonstrated that supplementation of high $\mathrm{Ca}$ could strengthen the benefits of a strongly negative DCAD diet on lipid metabolism in periparturient cows.

\section{CONCLUSIONS}

The findings of this study indicate that the blood acid-base balance could be altered and compensated metabolic acidosis could be induced by feeding acidogenic diets $(-24 \mathrm{mEq} / 100 \mathrm{~g} \mathrm{DM})$ to transition dairy cows. The compensated metabolic acidosis recovered to normal immediately within $24 \mathrm{~h}$ after calving once the consumption of acidogenic diet was stopped. The negative DCAD diet with a greater amount of $\mathrm{Ca}$ addition had a similar effect, and seemed to speed the normalization of acid-base balance after calving. On the basis of elevated serum total protein, albumin, and cholesterol, along with reduced triglycerides and NEFA, protein and lipid metabolism of periparturient cows benefited from the prepartum acidogenic diets. Our results overall provide additional evidence that high $\mathrm{Ca}$ supplementation in conjunction with a strongly negative DCAD diet was more favorable to the metabolic adaptation to lactation in dairy cows than the negative DCAD with low Ca.

\section{ACKNOWLEDGMENTS}

The authors thank the graduate students, faculty, and staff from University of Illinois and farm staff at the University of Illinois Dairy Research Unit during this trial. The authors gratefully acknowledge the funding support of Phibro Animal Health Corporation (Teaneck, NJ). The study of Xiangfei Zhang was 
financially supported from China Scholarship Council (Beijing, China). The authors have not stated any conflicts of interest.

\section{REFERENCES}

Amundson, L. A., A. D. Rowson, P. M. Crump, A. P. Prichard, A. A Cheng, C. E. Wimmler, M. Klister, S. R. Weaver, S. S. Bascom, D. E. Nuzback, K. P. Zanzalari, and L. L. Hernandez. 2018. Effect of induced hypocalcemia in nonlactating, nonpregnant Holstein cows fed negative DCAD with low, medium, or high concentrations of calcium. J. Anim. Sci. 96:5010-5023. https://doi.org/10.1093/jas/ sky371.

Apper-Bossard, E., J. L. Peyraud, P. Faverdin, and F. Meschy. 2006. Changing dietary cation-anion difference for dairy cows fed with two contrasting levels of concentrate in diets. J. Dairy Sci. 89:749760. https://doi.org/10.3168/jds.S0022-0302(06)72136-1.

Bazydlo, L. A. L., M. Needham, and N. S. Harris. 2014. Calcium, magnesium, and phosphate. Lab. Med. 45:e44-e50. https://doi.org/10 .1309/LMGLMZ8CIYMFNOGX.

Bikle, D. D., E. Gee, B. Halloran, M. A. Kowalski, E. Ryzen, and J. G. Haddad. 1986. Assessment of the free fraction of 25-hydroxyvitamin D in serum and its regulation by albumin and the vitamin D-binding protein. J. Clin. Endocrinol. Metab. 63:954-959. https: //doi.org/10.1210/jcem-63-4-954.

Bionaz, M., E. Trevisi, L. Calamari, F. Librandi, A. Ferrari, and G. Bertoni. 2007. Plasma paraoxonase, health, inflammatory conditions, and liver function in transition dairy cows. J. Dairy Sci. 90:1740-1750. https://doi.org/10.3168/jds.2006-445.

Block, E. 1994. Manipulation of dietary cation-anion difference on nutritionally related production diseases, productivity, and metabolic responses of dairy cows. J. Dairy Sci. 77:1437-1450. https://doi .org/10.3168/jds.S0022-0302(94)77082-X.

Chamberlin, W. G., J. R. Middleton, J. N. Spain, G. C. Johnson, M. R. Ellersieck, and P. Pithua. 2013. Subclinical hypocalcemia, plasma biochemical parameters, lipid metabolism, postpartum disease, and fertility in postparturient dairy cows. J. Dairy Sci. 96:7001-7013. https://doi.org/10.3168/jds.2013-6901.

Charbonneau, E., D. Pellerin, and G. R. Oetzel. 2006. Impact of lowering dietary cation-anion difference in nonlactating dairy cows: A meta-analysis. J. Dairy Sci. 89:537-548. https://doi.org/10.3168/ jds.S0022-0302(06)72116-6.

Constable, P. D., R. N. Streeter, G. J. Koenig, N. R. Perkins, H. M. Gohar, and D. E. Morin. 1997. Determinants and utility of the anion gap in predicting hyperlactatemia in cattle. J. Vet. Intern. Med. 11:71-79. https://doi.org/10.1111/j.1939-1676.1997.tb00076 .x.

Drackley, J. K., H. M. Dann, N. Douglas, N. A. J. Guretzky, N. B. Litherland, J. P. Underwood, and J. J. Loor. 2005. Physiological and pathological adaptations in dairy cows that may increase susceptibility to periparturient diseases and disorders. Ital. J. Anim. Sci. 4:323-344. https://doi.org/10.4081/ijas.2005.323.

Gelfert, C. C., S. Leonie Loeffler, S. Frömer, M. Engel, H. Hartmann, K. Männer, W. Baumgartner, and R. Staufenbiel. 2007. The impact of dietary cation anion difference (DCAD) on the acid-base balance and calcium metabolism of non-lactating, non-pregnant dairy cows fed equal amounts of different anionic salts. J. Dairy Res. 74:311-322. https://doi.org/10.1017/S0022029907002439.

Gelfert, C. C., L. M. Loeffler, S. Fromer, M. Engel, K. Männer, and R. Staufenbiel. 2010. Comparison of the impact of different anionic salts on the acid-base status and calcium metabolism in non-lactating, non-pregnant dairy cows. Vet. J. 185:305-309. https://doi .org/10.1016/j.tvjl.2009.06.013.

Glosson, K. M., X. Zhang, S. S. Bascom, A. D. Rowson, Z. Wang, and J. K. Drackley. 2020. Negative dietary cation-anion difference and amount of calcium in prepartum diets: Effects on milk production, blood calcium, and health. J. Dairy Sci. 103:7039-7054. https:// doi.org/10.3168/jds.2019-18068.
Goff, J. P. 2008. The monitoring, prevention, and treatment of milk fever and subclinical hypocalcemia in dairy cows. Vet. J. 176:50-57. https://doi.org/10.1016/j.tvjl.2007.12.020.

Goff, J. P. 2014. Calcium and magnesium disorders. Vet. Clin. North Am. Food Anim. Pract. 30:359-381. https://doi.org/10.1016/j .cvfa.2014.04.003.

Goings, R. L., N. L. Jacobson, D. C. Beitz, E. T. Littledike, and K. D. Wiggers. 1974. Prevention of parturient paresis by a prepartum, calcium-deficient diet. J. Dairy Sci. 57:1184-1188. https://doi.org/ 10.3168/jds.S0022-0302(74)85034-4.

Grünberg, W., S. S. Donkin, and P. D. Constable. 2011. Periparturient effects of feeding a low dietary cation-anion difference diet on acidbase, calcium, and phosphorus homeostasis and on intravenous glucose tolerance test in high-producing dairy cows. J. Dairy Sci. 94:727-745. https://doi.org/10.3168/jds.2010-3230.

Guo, J. Y., T. J. Pasquetti, and S. W. Kim. 2019. Lowering dietary cation-anion difference increases sow blood and milk calcium concentrations. J. Anim. Sci. 97:2927-2939. https://doi.org/10.1093/ jas/skz146.

Hansen, S. S., P. Nørgaard, C. Pedersen, R. J. Jørgensen, L. S. Mellau, and J. D. Enemark. 2003. The effect of subclinical hypocalcaemia induced by Na2EDTA on the feed intake and chewing activity of dairy cows. Vet. Res. Commun. 27:193-205. https://doi.org/10 .1023/A:1023340506782.

Higgins, C. 2011. Central venous blood gas analysis. Accessed Jul. 15, 2021. https://acutecaretesting.org/en/articles/central-venous -blood-gas-analysis.

Holcomb, C. S., H. H. Van Horn, H. H. Head, M. B. Hall, and C. J. Wilcox. 2001. Effects of prepartum dry matter intake and forage percentage on postpartum performance of lactating dairy cows. J. Dairy Sci. 84:2051-2058. https://doi.org/10.3168/jds.S0022 -0302(01)74649-8.

Horst, R. L., J. P. Goff, T. A. Reinhardt, and D. R. Buxton. 1997. Strategies for preventing milk fever in dairy cattle. J. Dairy Sci. 80:1269-1280. https://doi.org/10.3168/jds.S0022-0302(97)76056 -9 .

Janovick, N. A., and J. K. Drackley. 2010. Prepartum dietary management of energy intake affects postpartum intake and lactation performance by primiparous and multiparous Holstein cows. J. Dairy Sci. 93:3086-3102. https://doi.org/10.3168/jds.2009-2656.

Lean, I. J., P. J. DeGaris, D. M. McNeil, and E. Block. 2006. Hypocalcemia in dairy cows: Meta-analysis and dietary cation anion difference theory revisited. J. Dairy Sci. 89:669-684. https://doi .org/10.3168/jds.S0022-0302(06)72130-0.

Lee, S., S. Ok, H. Kwon, and D. Kim. 2015. Arterial and venous blood gas, electrolytes, biochemical and hematological values in healthy Korean native calves. J. Vet. Clin. 32:499-503. https://doi.org/10 $.17555 /$ jvc.2015.12.32.6.499.

Leno, B. M., C. M. Ryan, T. Stokol, D. Kirk, K. P. Zanzalari, J. D Chapman, and T. R. Overton. 2017. Effects of prepartum dietary cation-anion difference on aspects of peripartum mineral and energy metabolism and performance of multiparous Holstein cows. J. Dairy Sci. 100:4604-4622. https://doi.org/10.3168/jds.2016-12221.

Li, F. C., H. F. Liu, and Z. H. Wang. 2008. Effects of dietary cation-anion difference on calcium, nitrogen metabolism and relative blood traits of dry Holstein cows. Anim. Feed Sci. Technol. 142:185-191. https://doi.org/10.1016/j.anifeedsci.2007.07.003.

Liesegang, A., C. Chiappi, J. Risteli, J. Kessler, and H. D. Hess. 2007. Influence of different calcium contents in diets supplemented with anionic salts on bone metabolism in periparturient dairy cows. J. Anim. Physiol. Anim. Nutr. (Berl.) 91:120-129. https://doi.org/10 .1111/j.1439-0396.2006.00651.x.

Martinez, N., R. M. Rodney, E. Block, L. L. Hernandez, C. D. Nelson, I. J. Lean, and J. E. P. Santos. 2018. Effects of prepartum dietary cation-anion difference and source of vitamin D in dairy cows: Health and reproductive responses. J. Dairy Sci. 101:2563-2578. https://doi.org/10.3168/jds.2017-13740.

Martins, C. M. M. R., M. A. Arcari, K. C. Welter, J. L. Gonçalves, and M. V. Santos. 2016. Effect of dietary cation-anion difference on ruminal metabolism, total apparent digestibility, blood and re- 
nal acid-base regulation in lactating dairy cows. Animal 10:64-74. https://doi.org/10.1017/S1751731115001548.

Martins, C. M. M. R., M. A. Arcari, K. C. Welter, A. S. Netto, C. A. F. Oliveira, and M. V. Santos. 2015. Effect of dietary cation-anion difference on performance of lactating dairy cows and stability of milk proteins. J. Dairy Sci. 98:2650-2661. https://doi.org/10 $.3168 /$ jds.2014-8926.

Oba, M., A. E. Oakley, and G. F. Tremblay. 2011. Dietary Ca concentration to minimize the risk of hypocalcaemia in dairy cows is affected by the dietary cation-anion difference. Anim. Feed Sci. Technol. 164:147-153. https://doi.org/10.1016/j.anifeedsci.2011 .01 .002 .

Pardon, B., S. Ribbens, L. Van Damme, L. Vlaminck, A. Martens, and P. Deprez. 2018. Use of a national identification database to determine the lifetime prognosis in cattle with necrotic laryngitis and the predictive value of venous $\mathrm{pCO}_{2}$. J. Vet. Intern. Med. 32:1462-1470. https://doi.org/10.1111/jvim.15223.

Phillippo, M., G. W. Reid, and I. M. Nevison. 1994. Parturient hypocalcaemia in dairy cows: Effects of dietary acidity on plasma minerals and calciotrophic hormones. Res. Vet. Sci. 56:303-309. https://doi.org/10.1016/0034-5288(94)90146-5.

Reynolds, C. K., P. C. Aikman, B. Lupoli, D. J. Humphries, and D. E. Beever. 2003. Splanchnic metabolism of dairy cows during the transition from late gestation through early lactation. J. Dairy Sci. 86:1201-1217. https://doi.org/10.3168/jds.S0022-0302(03)73704 $-7$.

Ryan, K. T., A. R. Guadagnin, K. M. Glosson, S. S. Bascom, A. D. Rowson, A. J. Steelman, and F. C. Cardoso. 2020. Increased dietary calcium inclusion in fully acidified prepartum diets improved postpartum uterine health and fertility when fed to Holstein cows. Theriogenology 142:338-347. https://doi.org/10.1016/ j.theriogenology.2019.10.014

Sakha, M., M. Mahmoudi, and M. G. Nadalian. 2014. Effects of dietary cation-anion difference on milk fever, subclinical hypocalcemia and negative energy balance in transition dairy cows. Res. Opin. Anim. Vet. Sci. 4:69-73. http://www.roavs.com/pdf-files/ Issue-2-2014/69-73.pdf.

Salles, M. S. V., M. A. Zanetti, J. A. Negrão, F. A. Salles, T. M. C. Ribeiro, A. Saran Netto, and G. R. Del Claro. 2012. Metabolic changes in ruminant calves fed cation-anion diets with different proportions of roughage and concentrate. Rev. Bras. Zootec. 41:414-420. https://doi.org/10.1590/S1516-35982012000200026.

Seifi, H. A., M. Mohri, N. Farzaneh, H. Nemati, and S. V. Nejhad. 2010. Effects of anionic salts supplementation on blood $\mathrm{pH}$ and mineral status, energy metabolism, reproduction and production in transition dairy cows. Res. Vet. Sci. 89:72-77. https://doi.org/ 10.1016/j.rvsc.2010.01.013.

Stewart, P. A. 1983. Modern quantitative acid-base chemistry. Can. J. Physiol. Pharmacol. 61:1444-1461. https://doi.org/10.1139/y83 $-207$.

Trevisi, E., and A. Minuti. 2018. Assessment of the innate immune response in the periparturient cow. Res. Vet. Sci. 116:47-54. https: //doi.org/10.1016/j.rvsc.2017.12.001.
Vagnoni, D. B., and G. R. Oetzel. 1998. Effects of dietary cationanion difference on the acid-base status of dry cows. J. Dairy Sci. 81:1643-1652. https://doi.org/10.3168/jds.S0022-0302(98)75732 -7 .

Van Saun, R. J. 2006. Metabolic profiles for evaluation of the transition period. Pages 130-138 in Proceedings of the Annual Conference, American Association of Bovine Practitioners.

Weich, W., E. Block, and N. B. Litherland. 2013. Extended negative dietary cation-anion difference feeding does not negatively affect postpartum performance of multiparous dairy cows. J. Dairy Sci. 96:5780-5792. https://doi.org/10.3168/jds.2012-6479.

Weiss, W. P., E. Azem, W. Steinberg, and T. A. Reinhardt. 2015. Effect of feeding 25-hydroxyvitamin D3 with a negative cation-anion difference diet on calcium and vitamin D status of periparturient cows and their calves. J. Dairy Sci. 98:5588-5600. https://doi.org/ $10.3168 /$ jds.2014-9188.

Wu, W. X., J. X. Liu, G. Z. Xu, and J. A. Ye. 2008. Calcium homeostasis, acid-base balance, and health status in periparturient Holstein cows fed diets with low cation-anion difference. Livest. Sci. 117:7-14. https://doi.org/10.1016/j.livsci.2007.11.005.

Wu, Z., J. K. Bernard, K. P. Zanzalari, and J. D. Chapman. 2014. Effect of feeding a negative dietary cation-anion difference diet for an extended time prepartum on postpartum serum and urine metabolites and performance. J. Dairy Sci. 97:7133-7143. https:// doi.org/10.3168/jds.2014-8273.

Yıldızdaş, D., H. Yapıcıoğlu, H. L. Yılmaz, and Y. Sertdemir. 2004. Correlation of simultaneously obtained capillary, venous, and arterial blood gases of patients in a paediatric intensive care unit. Arch. Dis. Child. 89:176-180. https://doi.org/10.1136/adc.2002 .016261 .

Yu, X., Q. Peng, X. Luo, T. An, J. Guan, and Z. Wang. 2016. Effects of starvation on lipid metabolism and gluconeogenesis in yak. Asian-Australas. J. Anim. Sci. 29:1593-1600. https://doi.org/10 .5713 /ajas. 15.0868 .

Zhang, X., Z. Wang, A. M. Shah, M. F. Hassan, Q. Peng, R. Hu, H. Zou, C. Wang, B. Xue, L. Wang, and Y. Jiang. 2020. Production performance, metabolic profile and calcium-regulating hormones of transition dairy cows with different blood calcium status after parturition. Pak. Vet. J. 40:19-24. https://doi.org/10.29261/ pakvetj/2019.085.

\section{ORCIDS}

X. Zhang $\odot$ https://orcid.org/0000-0002-2186-5930

K. M. Glosson ๑ https://orcid.org/0000-0002-3268-385X

S. S. Bascom @ https://orcid.org/0000-0002-5934-3206

A. D. Rowson (1) https://orcid.org/0000-0002-6492-5120

J. K. Drackley ๑ https://orcid.org/0000-0002-4560-5594 